\title{
Efektifitas Metode Pengukuran Perilaku Seksual Remaja Usia 15-21 Tahun Berdasarkan Teknik Self Administered dan Interview-Based Questioner
}

\author{
Sri Rahayu Sanusi ${ }^{1}$, Lanova Dwi Arde $\mathbf{M}^{2}$ \\ Fakultas Kesehatan Masyarakat, Universitas Sumatera Utara, Indonesia \\ Email: lanovadwi@usu.ac.id
}

\begin{abstract}
The Effectiveness of Self-administered and Interview Based Questioner Method in the Reporting of Sexual Behavior among Young-People. The result of the Population Census shows about 41 million or $26 \%$ of the Indonesian population are adolescents aged 10-24 years. It will cause many problems, such as sexual behaviors. Sexual health problem is a sensitive issue that is both privacy and at the same time regulated by social and religious norms. This is one of the causes of getting a true number of young people's sexual behavior was difficult. So, we did a study to compare the effectiveness of self-administered and interview-based questioner methods to obtain a true number of young people's sexual behavior. It was a comparative-quantitative study, using 360 students of SMK X and Faculty of $Y$ in Medan City age 15-21 years as samples, gotten by simple random. This study showed that using a self-administered method, young people reported they got intercourse when they were with boy/girlfriend about 7,9\%, and using interviewbased questioner method 5,0\%. Young people who reported that ever got intercourse in a selfadministered method about $8,6 \%$, and using interview-based questioner method 3,3\%. The result showed there is different reporting young people's sexual behavior between self-administered method and interview-based questioner method. Young people were more likely to report sexual behaviors by self-administered method compared to interview-based questioner method.
\end{abstract}

Keywords: Adolescent, Interview-based questioner method, Self-administered method, Sexual behavior

\begin{abstract}
Abstrak: Efektifitas Metode Pengukuran Perilaku Seksual Remaja Usia 15-21 Tahun Berdasarkan Teknik Self Administered dan Interview-Based Questioner. Hasil Sensus Penduduk tahun 2010 menunjukkan bahwa sekitar 41 juta atau 26\% dari penduduk Indonesia adalah remaja berusia 10-24 tahun. Jumlah remaja yang cukup besar tersebut, akan menimbulkan banyak permasalahan yang dihadapi, Salah satu permasalahan yang menonjol dikalangan remaja adalah masalah perilaku seksual. Permasalahan kesehatan seksual merupakan isu sensitif yang bersifat pribadi dan pada waktu yang sama juga dibatasi ketat oleh norma sosial dan agama. Hal ini menjadi salah satu penyebab sulitnya mendapatkan angka akurat perilaku seksual pada remaja. Penelitian ini bertujuan untuk membandingkan keefektifan metode angket (self administered) dan wawancara (interview-based questioner) untuk mendapatkan kualitas data yang lebih baik. Penelitian ini merupakan penelitian deskriptif. Populasi penelitian adalah remaja usia 15-21 Tahun di Kota Medan, dengan lokasi penelitian di SMK N X dan Fakultas Y Medan. Sampel penelitian adalah remaja usia 15-21 Tahun yang memenuhi penelitian. Jumlah sampel penelitian 360 responden, yang dibagi secara merata di 2 lokasi penelitian, dan diambil secara acak sederhana. Penelitian ini menunjukkan bahwa dengan menggunakan metode pengisian kuesioner sendiri, remaja melaporkan bahwa mereka melakukan hubungan seksual ketika mereka sedang bersama dengan pacarnya adalah sekitar 7,9\%, dan menggunakan metode kuesioner berbasis wawancara sebesar 5,0\%. Remaja yang melaporkan bahwa pernah melakukan hubungan seksual dalam metode self-administered sekitar 8,6\%, dan menggunakan metode kuesioner berbasis wawancara $3,3 \%$. Hasilnya menunjukkan ada perbedaan pelaporan perilaku seksual remaja antara metode selfadministered dan metode kuesioner berbasis wawancara. Remaja lebih cenderung melaporkan perilaku seksual dengan metode self-administered dibandingkan dengan metode kuesioner berbasis wawancara.
\end{abstract}

Kata kunci: Remaja, Metode Interview-based questioner, Metode Self administered, Perilaku seksual 


\section{PENDAHULUAN}

Jumlah penduduk menunjukkan bahwa sekitar 41 juta atau $26 \%$ dari penduduk Indonesia adalah remaja berusia 10-24 tahun (BPS, BKKBN, Kemenkes, ICF, 2013). Remaja merupakan salah satu komponen dari gatra demografi pada astagatra ketahanan nasional, memiliki pengaruh yang besar bagi keberlangsungan kehidupan Indonesia. Jika Indonesia berhasil mendidik para remajanya saat ini untuk mampu mengekspresikan gairah masa mudanya dengan hal yang positif, jauh dari perilaku seksual pranikah, dan bertanggung jawab penuh dengan aktivitas seksualnya baik dari segi agama, biologi, dan moral, maka sangat mungkin Indonesia di masa depan akan menjadi negara yang sejahtera. Namun tidak ada yang bisa diharapkan jika remaja Indonesia sibuk dengan perilaku seks bebas dan perilaku seksual pranikah (Rinta, 2015). Karena pada kenyataannya, jumlah remaja yang cukup besar tersebut akan menimbulkan banyak permasalahan yang dihadapi sehingga perlu mendapat perhatian khusus, salah satu permasalahan yang menonjol dikalangan remaja adalah masalah perilaku seksual.

Pada masa remaja, informasi tentang masalah seksual sudah seharusnya mulai diberikan untuk menghindari agar remaja tidak mencari informasi sendiri dari teman atau sumber-sumber lain yang tidak jelas atau bahkan keliru sama sekali (Rinta, 2015). Berdasarkan data yang dikeluarkan oleh Kementerian Kesehatan RI (2014), diketahui 3,7\% remaja lakilaki dan 1,3 remaja perempuan diketahui melakukan hubungan seksual pranikah pada tahun 2007. Data ini kemudian diperbaharui lagi pada tahun 2012, dimana diperoleh data bahwa $4,5 \%$ remaja laki-laki dan $0,7 \%$ remaja perempuan diketahui melakukan hubungan seksual pranikah.

Setiap prilaku seksual remaja pranikah dipengaruhi oleh banyak hal, selain dari faktor pengetahuan juga dipengaruhi oleh faktor budaya, orang lain yang dianggap penting, media massa, lembaga pendidikan, lembaga agama, dan emosi dari dalam individu. Sikap seksual pranikah remaja bisa berwujud positif ataupun negatif, sikap positif kecenderungan tindakan adalah mendukung seksual pranikah sedangkan sikap negatif kecenderungan tindakan ialah menghindari seksual pranikah (Sarwono, 2011).

Permasalahan kesehatan seksual merupakan isu sensitif yang bersifat pribadi dan pada waktu yang sama juga dibatasi ketat oleh norma sosial dan agama, sehingga menjadi salah satu penyebab sulitnya mendapatkan angka akurat perilaku seksual pada remaja. Beberapa metode pengumpulan data pernah digunakan untuk mendapatkan angka akurat tersebut diantaranya adalah pengisian kuesioner dan wawancara.

Pengisian kuesioner sendiri oleh responden pada dasarnya sangat mudah, efektif dan efesien dalam mengurangi biaya penelitian. Kekurangan dari pengisian kuesioner sendiri oleh responden, diataranya kecenderungan responden untuk menjawab pertanyaan tanpa membaca lebih teliti pertanyaan yang ditanyakan. Selain itu angka non-respond rate juga cenderung tinggi, terutama jika responden tidak mengerti dengan pertanyaan/ istilah yang digunakan dalam pertanyaan kuesioner (Dolezal, et al., 2012; Christensen, 2013).

Penggunaan metode wawancara juga memiliki kelebihan dan kekurangan. Metode wawancara dapat mengakibatkan underreporting/ tidak dilaporkan karena beberapa penyebab, diantaranya adanya rasa khawatir terhadap kerahasiaan jawaban, rasa takut untuk dinilai buruk, dan keinginan untuk dipandang baik oleh orang lain (Jaya, et al., 2008).

Beberapa survei di Indonesia ada yang juga menilai tentang perilaku seksual menggunakan teknik pengumpulan yang berbeda. Perbandingan hasil survei perilaku seksual remaja berdasarkan teknik pengumpulan data bisa dilihat dari hasil Survei Kesehatan Reproduksi Remaja Indonesia (SKRRI) Tahun 2012 dan Survei Terpadu Biologis dan Perilaku (STBP) 2011. Pada SKRRI pengumpulan data dilakukan dengan teknik wawancara yang dilakukan di rumah, sedangkan pengumpulan data STBP dilakukan dengan pengisian angket oleh remaja sendiri yang dilakukan di sekolah (SDKI, 2012; Kementerian Kesehatan RI, 2011).

Kota Medan, ibukota Propinsi Sumatera Utara merupakan kota besar ketiga di Indonesia setelah Jakarta dan Surabaya. Dibalik ambisinya untuk menjadi kota metropolitan, ada permasalah perilaku seksual pada remaja yang perlu diperhatikan. Riset yang dilakukan oleh Synovate Research (dalam Conrad dan Sarwono, 2010) di empat kota besar Indonesia (Jakarta, Bandung, Surabaya, dan Medan) menemukan bahwa 44\% dari 242 partisipan survey memiliki pengalaman seksual pranikah sejak usia 16 sampai 18 tahun, sementara $16 \%$ partisipan melakukannya pertama kali sejak usia 13 sampai 15 tahun. Angka remaja yang mengaku pernah melakukan perilaku ini dicurigai masih under-reporting. 
Berdasarkan permasalahan di atas, maka dilakukan penelitian untuk membandingkan gambaran perilaku seksual yang dilakukan dengan metode pengumpulan data menggunakan angket (self-administered) dan wawancara dengan kuesioner.

\section{METODE}

Penelitian ini merupakan penelitian komperatif-kuantitatif yang bertujuan untuk melihat perbedaan gambaran perilaku seksual remaja berdasarkan metode pengumpulan data. Populasi penelitian adalah remaja yang berumur 15-21 tahun di kota Medan. Sampel penelitian dipilih secara random di SMKN $\mathrm{X}$ dan mahasiswa Fakultas Y Kota Medan yang berumur 15-21 tahun yang memenuhi kriteria penelitian. Pemilihan kedua lokasi tersebut dengan alasan merupakan institusi belajar dengan siswa/mahasiswa yang berasal dari latar belakang sosial ekonomi yang sangat beragam.

Besar sampel yang digunakan dalam penelitian ini adalah sebesar 360 responden, dengan masing-masing lokasi penelitian berjumlah 180 sampel yang kemudian dibagi ke dalam 2 kelompok yaitu kelompok yang mengisi angket sendiri dan kelompok wawancara dengan panduan kuesioner.

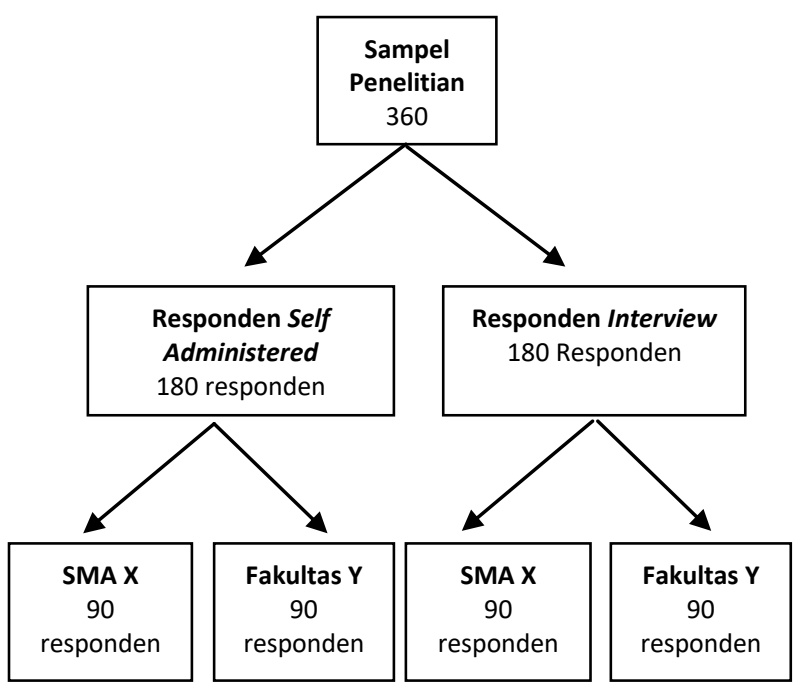

Data dianalisis secara deskriptif untuk mendapatkan gambaran perilaku seksual yang kemudian hasilnya dibandingkan berdasarkan metode pengumpulan data.

Penelitian ini telah mendapat persetujuan etik penelitian dari Komisi Etik Penelitian Kesehatan Fakultas Keperawatan Universitas Sumatera Utara Nomor: 1223/VI/SP/2017.

\section{HASIL}

Tabel 1. Gambaran Karakteristik Remaja

\begin{tabular}{|c|c|c|c|c|}
\hline \multirow[t]{2}{*}{ Variabel } & \multicolumn{2}{|c|}{$\begin{array}{c}\text { Self } \\
\text { administered } \\
\mathrm{n}=180\end{array}$} & \multicolumn{2}{|c|}{$\begin{array}{c}\text { Interview } \\
\text { based } \\
\text { questioner } \\
\mathrm{n}=180\end{array}$} \\
\hline & $\mathbf{n}$ & $\%$ & n & $\%$ \\
\hline \multicolumn{5}{|l|}{ Jenis Kelamin } \\
\hline Laki-laki & 74 & 41,1 & 77 & 42,8 \\
\hline Perempuan & 106 & 58,9 & 103 & 57,2 \\
\hline \multicolumn{5}{|l|}{ Umur } \\
\hline $15-18$ & 93 & 51,7 & 93 & 51,7 \\
\hline $19-21$ & 87 & 48,3 & 87 & 48,3 \\
\hline \multicolumn{5}{|l|}{ Tinggal dengan } \\
\hline Orang Tua & 106 & 58,9 & 111 & 61,7 \\
\hline Keluarga & 15 & 8,3 & 24 & 13,3 \\
\hline Lainnya & 59 & 32,8 & 45 & 25,0 \\
\hline \multicolumn{5}{|l|}{ Pendidikan Ayah } \\
\hline SD/ lebih rendah & 20 & 11,1 & 11 & 6,1 \\
\hline Tamat SMP & 15 & 8,3 & 11 & 6,1 \\
\hline Tamat SMA & 100 & 55,6 & 91 & 50,0 \\
\hline $\begin{array}{l}\text { Tamat Perguruan } \\
\text { Tinggi }\end{array}$ & 45 & 25,0 & 68 & 37,8 \\
\hline \multicolumn{5}{|l|}{ Pendidikan Ibu } \\
\hline SD/ lebih rendah & 19 & 10,6 & 15 & 8,3 \\
\hline Tamat SMP & 22 & 12,1 & 19 & 10,6 \\
\hline Tamat SMA & 86 & 46,4 & 81 & 45,0 \\
\hline $\begin{array}{l}\text { Tamat Perguruan } \\
\text { Tinggi }\end{array}$ & 52 & 28,9 & 65 & 36,1 \\
\hline
\end{tabular}

Dari hasil analisis pada tabel 1 didapatkan distribusi karakteristik sampel pada pengambilan data dengan metode self administered dan interview based questioner hampir merata. Responden dari penelitian ini sebagian besar adalah remaja perempuan $(58 \%)$. Rata-rata umur responden 17,4 tahun, dengan distribusi $51,7 \%$ berumur antara $15 \mathrm{~s} / \mathrm{d} 18$ tahun. Umumnya responden masih tinggal dengan orang tua. Berdasarkan latar belakang pendidikan orang tua, sekitar 50\% remaja tingkat penddikan ayah maupun ibu adalah tamatan SMA. Hanya sekitar $30 \%$ orang tua remaja yang berlatar pendidikan tamat perguruan tinggi, selain itu tamatan SMP (ayah 7\%, ibu 11\%), dan tamatan SD/lebih rendah sekitar $9 \%$ baik ayah mauapun ibu. 
Tabel 2. Perbandingan Proporsi Perilaku Seksual Remaja dalam Berpacaran Berdasarkan Metode Pengumpulan Data

\begin{tabular}{|c|c|c|c|c|}
\hline \multirow[t]{2}{*}{$\begin{array}{l}\text { Perilaku Seksual } \\
\text { dalam Berpacaran }\end{array}$} & \multicolumn{2}{|c|}{$\begin{array}{c}\text { Self } \\
\text { administered } \\
\mathrm{n}=132\end{array}$} & \multicolumn{2}{|c|}{$\begin{array}{l}\text { Interview } \\
\text { based } \\
\text { questioner } \\
\mathrm{n}=140\end{array}$} \\
\hline & $\mathbf{n}$ & $\%$ & $\mathbf{n}$ & $\%$ \\
\hline Pegangan Tangan & 112 & 84,8 & 111 & 79,3 \\
\hline Cium Pipi & 63 & 47,7 & 65 & 46,4 \\
\hline Cium Bibir & 38 & 28,8 & 38 & 27,3 \\
\hline $\begin{array}{l}\text { Meraba Bagian } \\
\text { Sensitif Tubuh }\end{array}$ & 22 & 16,7 & 24 & 17,3 \\
\hline $\begin{array}{l}\text { Melakukan } \\
\text { Hubungan Seksual }\end{array}$ & 10 & 7,4 & 8 & 5,7 \\
\hline
\end{tabular}

Hasil analisis menunjukkan bahwa melalui metode self administered, sebanyak 132 (73,3\%) dan melalui metode interview based questioner sebanyak $140(77,8 \%)$ remaja mengaku pernah memiliki pacar. Gambaran selanjutnya tentang perilaku seksual dalam berpacaran mereka menunjukkan proporsi yang tidak begitu berbeda antara metode self administered dan interview based questioner. Proporsi remaja yang pegangan tangan ketika berduaan dengan pacarnya sekitar $62 \%$, cium pipi $35 \%$, cium bibir $21 \%$, meraba bagian sensitif tubuh $12 \%$, dan yang mengaku pernah melakukan hubungan seksual dengan pacar sekitar 5\%.

Tabel 3. Perbandingan Proporsi Pengalaman Perilaku Seksual Remaja Berdasarkan Metode Pengumpulan Data

\begin{tabular}{lcccr}
\hline \multirow{1}{*}{ Variabel } & \multicolumn{2}{c}{$\begin{array}{c}\text { Self } \\
\text { administered }\end{array}$} & \multicolumn{2}{c}{$\begin{array}{c}\text { Interview } \\
\text { based } \\
\text { questioner }\end{array}$} \\
\cline { 2 - 6 } & $\mathbf{n}$ & $\%$ & $\mathbf{n}$ & $\%$ \\
\hline $\begin{array}{l}\text { Pernah melakukan } \\
\text { hubungan seksual }\end{array}$ & 16 & 8,9 & 8 & 4,5 \\
\hline Pertama kali melakukan dengan: & & & \\
\hline Teman & 2 & 12,5 & 0 & 0,0 \\
Pacar & 12 & 75,0 & 6 & 75,0 \\
Pekerja seks & 2 & 12,5 & 2 & 25,0 \\
\hline Tempat pertama kali melakukan: & & & \\
\hline Rumah & 11 & 68,7 & 5 & 62,5 \\
sendiri/pasangan & 4 & 25,0 & 0 & 0,0 \\
Hotel & 0 & 0,0 & 2 & 25,0 \\
Tempat kos & 0 & 0,0 & 1 & 12,5 \\
Sekolah/asrama & 1 & 6,2 & 0 & 0,0 \\
Kendaraan & \multicolumn{3}{c}{}
\end{tabular}

Selanjutnya, terlihat ada perbedaan hasil dari remaja yang mengaku pernah melakukan hubungan seksual antara metode self adiministered dan interview based questioner. Berdasarkan metode self administered sebanyak
16 orang $(8,9 \%)$ remaja pernah melakukan hubungan seksual, sedangkan menggunakan metode interview based questioner sebanyak 8 orang $(4,5 \%)$ yang mengaku pernah melakukan hubungan seksual. Artinya proporsi remaja yang mengaku pernah melakukan hubungan seksual dengan menggunakan metode self administered dua kali lebih besar dibandingkan proporsi dengan menggunakan metode interview based questioner.

Disamping itu, hal yang cukup menarik didapatkan bahwa remaja tidak hanya melakukan hubungan seks pertama kali dengan pacarnya, tetapi ada juga yang melakukan pertama kali dengan teman dan yang mengejutkan mereka yang melakukan dengan pekerja seks. Walaupun hasil menunjukkan proporsi terbesar adalah mereka melakukan dengan pacarnya, baik melalui metode self administered maupun interview based questioner.
Tabel 4. Perbandingan Gambaran Perilaku Seksual Teman Sebaya Remaja Berdasarkan Metode Pengumpulan Data

\begin{tabular}{lcccc}
\hline $\begin{array}{l}\text { Perilaku Seksual } \\
\text { Teman Sebaya }\end{array}$ & \multicolumn{2}{c}{$\begin{array}{c}\text { Self } \\
\text { administered }\end{array}$} & \multicolumn{3}{c}{$\begin{array}{c}\text { Interview } \\
\text { based } \\
\text { questioner }\end{array}$} \\
\cline { 2 - 6 } & $\mathbf{n}$ & $\%$ & n & $\%$ \\
\hline $\begin{array}{l}\text { Memiliki teman } \\
\text { yang pernah } \\
\text { melakukan } \\
\text { hubunan seksual }\end{array}$ & 111 & 61,7 & 89 & 49,4 \\
\hline $\begin{array}{l}\text { Merasa terdorong } \\
\text { melakukan } \\
\text { hubungan seksual }\end{array}$ & 23 & 12,8 & 21 & 11,7 \\
\hline
\end{tabular}

Walaupun hasil pengumpulan data didapatkan angka remaja yang pernah melakukan hubungan seksual cukup rendah, tetapi ketika ditanya teman responden yang pernah melakukan hubungan seksual, sekitar 50\% remaja mengaku memiliki teman yang pernah melaukan hubungan seksual, dengan perbedaan berdasarkan metode self administered sebanyak $111(61,7 \%)$ remaja dan metode interview based questioner sebanyak $89(49,4 \%)$ remaja memiliki teman yang pernah melakukan hubungan seksual.

\section{PEMBAHASAN}

Hasil penelitian menunjukkan bahwa proporsi perilaku berpacaran remaja pegangan tangan dan ciuman pipi cukup tinggi, baik dengan metode self administered maupun dengan interview based questioner Hal ini menunjukkan bahwa remaja cukup terbuka terhadap perilaku 
berpacaran yang masih dianggap wajar pada zaman sekarang. Selanjutnya proporsi perilaku berpacaran remaja yang dianggap cukup berisiko seperti ciuman bibir, meraba bagian sensitif tubuh, dan melakukan hubungan seksual cukup rendah.

Dari hasil analisis data di atas dapat dilihat tidak ada perbedaan yang bermakna antara proporsi perilaku berpacaran remaja antara metode self administered dan interview based questioner. Ketika ditanya lebih jauh tentang pernah melakukan hubungan seksual terlihat proporsi yang menjawab "pernah" dengan menggunakan metode self administered dua kali lebih tinggi dibandingkan dengan metode interview based questioner.

Hasil ini sejalan dengan penelitian Gutierrez dan Torres-Pereda (2009) di Mexico yang menunjukkan bahwa angka remaja yang mengaku pernah melakukan hubungan seksual dengan menggunakan metode self administered 2,3 lebih tinggi dibandingkan dengan menggunakan metode wawancara. Sedangkan pada penelitian Garvin (2018) dengan metode kuesioner online, diketahui $23,4 \%$ responden mengaku sudah pernah melakukan hubungan seksual dengan pacarnya, diketahui bahwa usia pertama kali memulainya berada pada kisaran 14 tahun hingga 20 tahun.

Lebih jauh dijelaskan bahwa remaja cenderung untuk tidak melaporkan perilaku berisiko yang mereka lakukan pada saat survei dengan metode wawancara, dan hal ini akan meningkat ketika survei dilakukan di rumah yaitu tempat/ lingkungan dimana perilaku berisiko biasanya dirahasiakan.

Menurut Heweet (2004), penelitian tentang perilaku seksual remaja di Negara berkembang dengan menggunakan metode wawancara dengan panduan kuesioner menunjukkan hasil yang tidak konsisten dan irasional.

Berbeda dengan hasil penelitian di atas, Kim, et al (2008), menunjukkan hasil bahwa mengungkap informasi yang sensitif lebih efektif dengan menggunakan teknik wawancara dibandingkan dengan pengisian angket.

Penelitian ini juga didapatkan bahwa tempat pertama kali remaja melakukan hubungan seksual adalah di rumah sendiri atau di rumah pasangan mereka. Hal ini sesuai dengan penelitian yang dilakukan oleh Perkumpulan Keluarga Berencana Indonesia (PKBI) yang menunjukkan data remaja yang mengaku pernah melakukan hubungan seksual, $89 \%$ responden dilakukan di rumah sendiri (Mustafa, 2012), serta penelitian yang dilakukan Garvin (2018), dimana rumah merupakan tempat pertama remaja melakukan hubungan seks dengan pacarnya.

Menurut psikolog, remaja cenderung melakukan perilaku seksual ditempat yang mereka tahu situasi dan kondisinya kapan saja dalam keadaan aman atau tidak. Rumah sendiri adalah salah satu tempat yang mereka tahu bagaimana kondisinya, sehingga tidak heran lebih dari $50 \%$ remaja baik yag menjawab melalui self administered maupun interview based questioner melakukan hubungan seksual pertama kali di rumah sendiri/pasangan (Sarwono, 2011).

Pasangan hubungan seksual pertama kali responden sebanyak $75 \%$ adalah pacar sendiri dan $25 \%$ dengan pekerja seks komersial. Hasil penelitian yang sama juga diperoleh oleh Pratiwi dan Basuki yang mendapatkan sebesar 88\% pasangan hubungan seksual pertama remaja yang belum menikah adalah pacar sendiri, dan sekitar 4\% dengan pekerja seks komersial (Pratiwi dan Basuki, 2010).

Hasil penelitian menunjukkan sekitar 50\% remaja mengakui memiliki teman yang pernah melakukan hubungan seksual, dan sekitar $12 \%$ merasa terdorong untuk melakukan hubungan seksual karena hal tersebut. Hasil ini sesuai dengan penelitian Umaroh yang menyatakan bahwa faktor yang mempengaruhi perilaku berpacaran berisiko adalah pengaruh teman yang pernah melakukan hubungan seksual dengan pacar (Umaroh, 2015).

Jika dilihat perbandingan angka proporsi remaja yang mengakui pernah melakukan hubungan seksual dengan angka memiliki teman yang pernah melakukan hubungan seksual cukup tinggi. Sehingga bisa diasumsikan bahwa masih banyak remaja yang menyembunyikan/ tidak mengakui perilaku seksual mereka.

\section{SIMPULAN}

Hasil penelitian ini dapat disimpulkan bahwa terdapat perbedaan angka perilaku seksual remaja berdasarkan metode pengumpulan data self administered dan metode interview based questioner, terutama pada pertanyaan yang sangat sensitif yaitu pernah melakukan hubungan seksual. Untuk pertanyaan yang tidak sensitif menunjukkan tidak ada perbedaan proporsi berdasarkan kedua metode pengukuran tersebut. 


\section{DAFTAR PUSTAKA}

Badan Pusat Statistik (BPS), Badan Kependudukan dan Keluarga Berencana Nasional (BKKBN), Kementerian Kesehatan (Kemenkes), dan ICF International. (2013). Indonesia Demographic and Health Survey 2012. Jakarta: BPS, BKKBN, Kemenkes and ICF International.

Christensen, et al. (2013). Effect of survey mode on reponse patterns: comparison of faceto-cace and self- administered modes in health surveys. Journal of Public Health, Vol 24, No 2, 327-332

Conrad, C. S., \& Sarwono, S. W. (2010). Hubungan pola asuh orangtua dengan perilaku seksual remaja dalam berpacaran. Jurnal Ilmiah Psikologi MIND SET, 1(02), 118-123.

Dolezal, C., Marhefka, S. L., Santamaria, E. K., Leu, C. S., Brackis-Cott, E., \& Mellins, C. A. (2012). A comparison of audio computer-assisted self-interviews to faceto-face interviews of sexual behavior among perinatally HIV-exposed youth. Archives of sexual behavior, 41(2), 401-410.

Garvin, G. (2018). Harga Diri, Konformitas dan Perilaku Seksual Remaja Dalam Berpacaran. Jurnal Ilmu Perilaku, 2(1), 54-60.

Gutierrez, JP., dan Torres-Pereda,P. 2009. Acceptability and reliability of an adolescent risk behavior questionnaire administered with audio and computer support: Revista Panamericana de Salud Publica/ Pan American Journal of Public Health, 25(5), hal. 418-422. http://www.scielosp.org/pdf/rpsp/v25n5/06

Hewett, PC, Mensch BS, AS Erulkar. (2004). Consistency in the reporting of sexual behavior by adolescent girl in Kenya: a comparison of interviewing methods. Sexually Transmitted Infections Journal. DOI: 10.1136/sti.2004.013250.

Jaya, Hindin, M. J., Ahmed, S. (2008). Differences in Young People's Report of
Sexual Behaviors According to Interview Methodology: A Randomized Trial in India. American Journal of Public Health. 98(1), hal. 169-174. http://www.ncbi.nlm.nih.gov/.

Kementerian Kesehatan RI. (2011). Surveilans Terpadu Biologis dan Perilaku. Jakarta: Direktorat Jenderal Pengendalian Penyakit dan Penyehatan Lingkungan.

Kementerian Kesehatan RI. (2014). Pusat data dan informasi Kementrian Kesehatan RI. Jakarta Selatan: Kementerian Kesehatan RI. http://www.depkes.go.id/download.php?fie $=$ download/pusdatin/infodatin/infodatin $\% 2$ Oreproduksi\%20remaja-ed.pdf.

Kim, et al. (2008). Comparison of 3 Data Collection Methods for Gathering Sensitive and Less Sensitive Information. Ambulatory Pedriatics. Vol 8 No 4 JulyAugust 2008.

Mustafa, Jejen (ed). (2012). Pendekatan Holistik: Pendekatan Lintas Perspektif. Jakarta: Prenada Media.

Pratiwi, NL., Basuki, H. (2010). Analisis Hubungan Perilak Seks pertama kali tidak aman pada remaja usia 15-24 tahun dan kesehatan reproduksi. Buletin Penelitian Sistem kesehatan. Vol 13 No 4 Oktober 2010.

Rinta, L. (2015). Pendidikan Seksual Dalam Membentuk Perilaku Seksual Positif Pada Remaja Dan Implikasinya Terhadap Ketahanan Psikologi Remaja. Jurnal Ketahanan Nasional, 21(3), 163-174.

Sarwono, S. W. (2011). Psikologi Remaja edisi revisi. Jakarta: Rajawali Pers.

Survei Demografi Kesehatan Indonesia. (2012). Kesehatan Reproduksi Remaja. Jakarta: BPS.

Umaroh, Ayu Khoirul. (2015). Hubungan antara faktor internal dan eksternal dengan perilaku seksual pranikah remaja Indonesia. Jurnal Kesehatan Masyarakat Andalas, 10, 65-75. 